\title{
Erratum to: Posttraumatic Recovery to Distress Symptoms Ratio: A Mediator of the Links Between Gender, Exposure to Fire, Economic Condition, and Three Indices of Resilience to Fire Disaster
}

\author{
Yohanan Eshel · Hadeal Majdoob - Marina Goroshit
}

Published online: 2 July 2014

(c) Springer Science+Business Media New York 2014

Erratum to: Community Ment Health J

DOI 10.1007/s10597-014-9734-7

Coauthor Marina Goroshit was erroneously not submitted and published in the author group of the original paper.

This erratum is to include Marina Goroshit as coauthor of the paper.

The online version of the original article can be found under doi:10.1007/s10597-014-9734-7.

Y. Eshel $(\bowtie) \cdot$ H. Majdoob

Department of Psychology, University of Haifa, Mount Carmel,

31905 Haifa, Israel

e-mail: yeshel@psy.haifa.ac.il

H. Majdoob

e-mail: h_majdoob@hotmail.com

Y. Eshel · M. Goroshit

Tel Hai College, Tel Hai, Israel

M. Goroshit

e-mail: marina.and.mark@gmail.com 